\title{
LEISHMAN - SOLDIER AND SCIENTIST
}

\author{
Major-General M. H. P. SAYERS, O.B.E., Q.H.P., M.D., F.C.Path.
}

Director of Army Pathology

THE hundred years that have passed since William Leishman was born have given him a secure and unique position in the annals of our Corps. The fresh start given to the Army. Medical Services by the Royal Warrant published on June 23rd, 1898; was accorded an enthusiastic welcome by the leaders of the profession. But it demanded men of the first quality to fulfil the high hopes expressed that in future the Army would, in the words of Lord Lister " be served by the best elements of our profession ". The hour indeed produced the men and Leishman, who at the time was serving as a company officer at Netley, was one of the foremost. He had recently returned from India where he had served in the Waziristan expedition of 1894-95 gaining the Frontier Medal and Clasp. At Netley he infused something of the glamour and romance of the East into the sombre corridors of the Royal Victoria Hospital.

Here he came under the spell of Almroth Wright in the flood tide of exciting new ideas. In his laboratories he was to learn the meticulous techniques which were to characterise all his work. He soon revealed a natural aptitude for research and combined the ability to attend to minutiae of scientific investigation with a capacity to visualise the important practical application of results. Yet he retained a modest and reserved approach and Wright used to say that Leishman, before the turn of the century, did not realise his own splendid capabilities for research.

Although Leishman spent much of his spare time in the laboratory he also found time for sport and entered into the activities of the station. He was a keen sailor and shared a yacht on Southampton Water. He was also an accomplished musician and much in demand as a pianist at unit socials.

In the wards it was soon realised that Leishman was a first rate clinician as well as an immaculate officer. Furthermore he could inculcate good manners and discipline in a quiet and unassuming way. "All of us, young officers full of curiosity about the personalities and types likely to be met with in our military service", wrote a surgeon on probation, "were delighted with Leishman, who stood for all that was most attractive in the career we had chosen ".

Soon Leishman was collaborating with Wright whose pioneer work on anti-typhoid vaccination was showing such promise. But the authorities were reluctant at first to advise its general adoption. Fierce controversies ensued and at times emotional factors tended to cloud the issues. Kipling was born in the month after Leishman and lines taken from the poem appended to his story Regulus could be said to epitomise the prevailing view of the activities of "Wright's men" at this time:

\section{"Some cultivate in broths impure \\ The clients of our body-these, Increasing without Venus, cure, Or cause, disease."}

Certainly there was no love lost between Wright and Bruce and it was as a result of a report by Bruce in 1902 that anti-typhoid vaccination was suspended while further 
investigations were done. This gave Leishman his great opportunity and he was largely responsible for the detailed studies that followed in the laboratory and the field over the next eight years. They culminated in the masterly 1912 Report of the Anti-typhoid Committee which until recently formed the most impressive evidence available in favour of vaccination. Of this report Leishman was the heart and soul and his part in the prevention of enteric was later to earn the tribute from the Secretary of State for War that he deserved as much of his country as the man who had invented the Lewis gun. (Lord Middleton speaking on June 8th, 1920).

Meanwhile, Leishman had succeeded Wright as Professor of Pathology. Such appointments in those days were made with great ceremony. The proposal was submitted in long hand for the approval of the Secretary of State by Keogh-then Deputy Director General. But first it had to be approved by the Commander in Chief-Field Marshal Lord Roberts, not long returned from South Africa. He saw no reason to dissent and finally the approval of the Secretary of State sealed the matter. The date was 26 th December, 1902.

Thus Leishman became the first serving officer to occupy the chair of pathology which since its foundation in 1860 had only had two incumbents-Sir William. Aitken (1860-92) and Dr. A. E. Wright (1892-1903)-both civilians.

Before this Leishman had turned his attention to the Romanowsky stains. The solution which came to be known by his name combined both fixative and staining principles. The addition of distilled water to the stain on the slide was found to enhance its effect to a remarkable degree This stain which embodied new and original features greatly simplified and hastened the staining of blood films and opened the way to new discoveries in parasitology. It was described at the time as " as great an advance on previous methods of staining as the breech loading gun was an advance on the muzzle loader".

It was with the aid of this new and beautiful method that Leishman first observed in the spleen of a fatal case of "dum dum fever" the binucleate cells which came to be known as Leishman-Donovan bodies. Similar appearances had originally been described by D. D. Cunningham in a "Delhi boil" in 1885 but attracted little attention. Although Donovan's observations in Madras undoubtedly drew attention to a new parasitic disease of man, Leishman's claim to priority was accepted. Indeed Bruce felt that all the credit should have gone to Leishman and he acidly remarked regarding the rival claims-for many had played their part - " They might as well be called the Leishman-Donovan-Ross-Bentley-Manson-Low etc. bodies". He was not blaming these distinguished men of course and least of all Donovan. He said it was a case of being saved from one's friends.

The vaccine, the stain and the parasite - these three were his main contributions from the bench. But there were several others which have tended to be forgotten with the passage of time. One, however, requiring mention was his work on spirochaetes. These organisms used to be in the province of the parasitologist and Leishman had an intense interest in the causative organisms of relapsing fever. He returned to this subject time and again. Although his theory of the granular phase of Spirochaeta duttoni in the African tick is not yet finally proven, the brilliant description of his laborious experiments elicited the highest praise. "Seldom have I heard," said Dr. Sambon, " of experiments carried out in such a masterly way". 
Like many of the great contributors to our knowledge of tropical disease, Leishman's work was done in this country. His tropical service ended with his return from India in 1897 before his laboratory work had begun. His work at the bench virtually ceased when in 1913 he was appointed expert in tropical diseases to the newly formed Medical Advisory Board. In the same year he was made one of the original members of the Medical Research Committee-the forerunner of the Medical Research Council.

Tribute must be paid to Leishman's outstanding gifts as a teacher which earned the praise of distinguished contemporaries including Robert Muir. He spoke without notes and his lectures were models of lucidity. At Millbank he preserved the high standards of instruction established by his two illustrious predecessors and which have been faithfully maintained by his successors ever since. He was also a good organiser. As the result of his efforts, at the outset of the Great War, the Roval Army Medical Corps was fully prepared to deal with many of the problems which confronted it. There was a body of officers and men properly trained in pathology. Vast reserves of vaccines were available. Over 25 million c.cm. of anti-enteric vaccines were issued from the Vaccine Department of the Royal Army Medical College between August 4th, 1914 and 31st July, 1919 besides over 8 million c.cm. of cholera vaccine For this Colonel D. Harvey was immediately responsible.

Before the Great War there were only eight specialist appointments for pathologists at home and three abroad. By 1917 there were 97 pathologists in France alone, only four of whom were regular officers. These figures taken from the chapter, written by Leishman, on the Organisation of the Pathology Service in the Medical History of the Great War, illustrate the indebtedness of the Army to the civilian profession. Leishman had been appointed Adviser in Pathology to the D.G.M.S. of the British Armies in France and his standing with the civilian medical profession ensured the most harmonious relations. He fostered an intimate association between the ward and the laboratory which as he put it. " makes so strongly for good work and for the benefit alike of patient, clinician and pathologist ". This prevented to a large extent cases of trench fever swelling the numbers of enteric suspects. His visits to the numerous laboratories in France were anticipated with pleasure by all his colleagues.

In 1919 Leishman became the first Director of Pathology. He organised the pathology service of the Army on lines which have stood the test of time. With its Director at the head and regional deputies and assistant directors in Commands at home and overseas, the speciality was given an identity and a sense of autonomy. This element of freedom felt in pathology as a speciality has been an important factor in attracting men with originality of thought and character to join the Royal Army Medical Corps. The results were seen at their best in India between the wars.

In 1923, Leishman was appointed Director General Army Medical Services and the brilliant research worker, teacher and practical pathologist, was to succeed in administration and command as he had done in science. He proved one of the great directorsgeneral of the Corps and in seeking an explanation it is as well to remember that he had spent the first ten years of his service performing general duties. His tenure was marked by another post-war lull in the popularity of service life among young medical men and there was great unrest in the Corps owing to financial stringency and shortages. A committee under the chairmanship of Sir Warren Fisher was appointed in 1926 to investigate the cause and make recommendations. Leishman's valuable contributions to its deliberations did much to help the decision to improve conditions of service, and its recommen- 
dations were later accepted by the Government. Although Leishman did not live to see the sequel, it would have given him the greatest satisfaction to know that this committee and its successor were to bring fresh life to the Corps. The new conditions recommended in 1933 had an immediate effect and attracted men of the first quality from the best medical schools at home and in the Commonwealth, many of whom are still serving today.

Another little known fact must be recorded. Leishman's great ambition was to maintain the high reputation won by the Corps during the Great War by fostering comradeship among all ranks. With this object in view he founded the R A.M.C. Association which still flourishes, uniting all ranks in thought and deed.

Leishman had an extraordinary gift for lucid, precise expression in the written and spoken word. He recorded everything he did and was a prolific contributor to the medical literature. His sense of fun is revealed in his writings where "cheerfulness was always breaking in". Thus his reference to a volunteer in a study of oral vaccines "as the officer concerned was one who holds both the Victoria Cross and the Distinguished Service Order we may believe that he held out longer than most "* His Harben, Linacre, Finlayson, Horace Dobell and numerous other lectures are models of their kind and he seemed equally at ease in French as in English. The meticulous way in which he presented the results of his work, the facility of expression and happy turn of phrase elicited the highest praise from the most critical audiences which included such famous figures as Sir Patrick Manson, Wenyon, Christophers and Rogers.

Throughout his career he received many honours. He was knighted in 1909 (when still a substantive major) and elected a Fellow of the Royal Society the following year. He was appointed C.B. in 1915, created K.C.M.G. in 1918 and K.C.B. in 1924. It gave him particular pleasure when in 1925 , he was elected a member of the Athenaeum under Rule II. This covers a small numcer of persons each year "of distinguished eminence in science, literature or the arts or for their public services".

After the Great War, Leishman suffered much ill health which ultimately led to his death. In spite of this he continued to live until the end to the limit of intellectual ability and physical capacity. It was a grievous loss, felt far beyond the confines of the Corps, when he died at the height of his powers.

Leishman was devoted to his family and universally beloved by his fellow men. Nearly forty years have passed since his death yet he is still remembered for his charm and simplicity of character "which could turn friends into brothers and potential rivals into friends". " His death" wrote a senior officer at the time " brought more poignant sorrow to the Royal Army Medical Corps than has ever been experienced in the whole of its history".

The century which has passed since Leishman's birth begins virtually at the origin of Army pathology itself. It ends at the dawn of a new medical era, the pattern of which is not yet clear. It is certain however that the new electronic equipment, the multiple channel autoanalysers and computer recording devices will have far reaching effects, the results of which have still to be seen.

Leishman was always looking ahead and receptive of new ideas. It is fitting therefore to end this tribute with this extract from one of his last public utterances:

"Finally it is only by contributing our full share to medical progress that we can hope to maintain the high prestige gained for our respective services by those who have. gone before us". To strive to do this is the best homage we can pay to his memory. *The officer concerned is believed to be Major-General H. E. M. Douglas, Y.C., C.B., C.M.G., D.S.O. 